After this, Tchernavin worked for the British Museum (Natural History), and his first assignment was the eollection of fishes made by the Titicaca Expedition of 1937. The taxonomic analysis of this rather uninteresting collection was given almost more than its share of meticulous labour by Tchernavin, who had, like all taxonomists, to cope with the shortcomings of his predecessors as well as with the limitations of his material. A museum analysis could scarcely go further, and this work will form a reliable basis for the study of ecological and genetic differentiation of these little fishes whenever someone finds it worth while. Tchernavin did not enjoy this work-nor the failure of the then editor of the Titicaca reports to appreciate it - and he accepted with great enthusiasm a suggestion that he should report on the oceanic fishes brought back by the "Discovery" expeditions. $\mathrm{He}$ took first the Stomiatoids, with the intention of studying the inter-relationships of the genera and families; but he became fascinated by the functional morphology of the head of Chaulodius and the movements involved in catching and swallowing prey. $\mathrm{He}$ soon found that current conceptions of the movements of the parts of the head and the fore part of the trunk in fishes were false or blurred, and he wrote the first account of these movements, both in the large-mouthed ocean predators and in familiar fishes like the salmon and cod, carried as far as morpho. logical analysis may go. The largest of these works, beautifully illustrated by Tchernavin himself, is now in the press for publication as a separate monograph by the Museum.

In October last he learned that his best friend during recent years was fatally ill. He abandoned his work at the Museum the better to care for her, and although his devoted nursing prolonged her life five months beyond medical expectation, he took his own life on March 31, the day following her death. Many weeks previously he had left the notes for this obituary among his papers where some colleague would eventually find them.

\section{ETHELWYNN Trewavas}

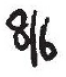

\section{Prof. H. B. Kirk}

Two or three yegrs bore his retirement, when a bronze plaque and tajlet were erected in honour of Harry Borrer Kifl, emeritus professor of biology, Victoria University College, Wellington, New Zealand, the tributes pad by different generations of his colleagues and Students showed the profound affection harbourg overywhere for that kindly and companionabl soul. He was an inspiring friend, of an old A. Nd cultured courtesy, quietly spoken, gently satirical on occasion, subtly humorous, but possessed of a strength of character which could make itself felt to some purpose-respecting his neighbours as he respected himself. He devoted his life to his students, and the effectiveness of his technique was mirrored by the high proportion of biology scholarships and honours won by his students year after year without intermission.

Prof. Kirk was born in England in 1859, and went to Auckland, New Zealand, in 1863. His father, Thomas Kirk, the New Zealand botanist, was born in Warwick and educated at Coventry, where, in 1850, he married Sarah Mattocks of that city. Prof. Kirk's elder brother, Thomas William Kirk, became prominent in New Zealand as the founder of the Government biological and horticultural depart- ments; thus those two brothers had a far-reaching influence in pioneering the biological services of the Dominion, the elder in the applied and the younger in the academic field.

As a pupil at the Auckland Grammar School and at Wellington College, Prof. Kirk stood high in classics, modern languages, mathematics and science. There being no university college yet established in Wellington, he graduated as an extra-mural student of the University of New Zealand, and in 1883 secured Mi.A. with honours in zoology and botany. At that time he was employed in the Education Department, where he rose to be assistant inspector of native schools; during the twenty-four years so occupied, he made full use of his travels to study the biology of the country and to understand humanity in all walks of life. In 1903, when he was appointed to the chair of biology at Victoria College, Wellington, as the first professor, he was well equipped for the magnificent work he was to carry on for forty years. There were no laboratories at the outset, and he commenced work in a single room of a kindergarten school at Thorndon, which was available only at night; but by his efforts there arose from that modest beginning the extensive and modern biology block of Victoria College; he lived to see this erected and to occupy it for some years until failing eyesight, but not spirit, put a period to his active career. $\mathrm{He}$ retired in 1944, and died at Hamilton on July 15, 1948, aged eighty-nine years. DAvid MrLLER

\section{Mr. R. A. Todd}

\section{6}

The death of Mr. R. A. Todd, coming so soon after that of Prof. Walter Garstang, has broken yet another link with thoseproneer marine biologists at work at the opgring of the present century. He was the eldest son of hir. and Mrs. H. S. Todd, of Norwich, where he wabloorn in 1877 ; educated at Paston Grammax Sthool, North Walsham, he graduated at the Unifersity of Leeds. It was in 1898 that Todd jopdthe staff of the Plymouth Laboratory of the Maine Biological Association as the director's assistant. The director was E. J. Allen, and the only other member of the scientific staff was Garstang, who was naturalist in charge of fishery investigations.

In those early days one of the first needs was to build up a knowledge of the marine fauna in the Plymouth neighbourhood, and Todd was well fitted for the purpose. He was an able and enthusiastic naturalist, and his name will always be linked with that of Allen in the reports of their well-known surveys of the Exe and Salcombe estuaries. Independently, Todd published an account of the invertebrate fauna of the bays between the Start and Exmouth, and to this day the "Plymouth Marine Fauna" is liberally sprinkled with his initials recording observations on many invertebrates.

In 1902 Todd was transferred to the laboratory at Lowestoft to assist in the international investigations in the North Sea which the Association was undertaking on behalf of the British Government. Here his faunistic knowledge proved invaluable and enabled him to produce his reports on the food of fishes which form the basis of our present knowledge. In 1910 the Lowestoft laboratory was transferred under the Board of Agriculture and Fisheries, and Todd remained there until 1912, when he joined the Fisheries Department as an inspector. In 1920 he was appointed a district fishery officer and returned 